\title{
Stereospecific Synthesis and Characterization of Oligodeoxyribonucleotides Containing an N2-(1-Carboxyethyl)-2'- deoxyguanosine
}

\author{
Huachuan Cao, Yong Jiang, and Yinsheng Wang* \\ Department of Chemistry, University of California, Riverside, CA 92521-0403
}

\begin{abstract}
Methylglyoxal is a highly reactive $\alpha$-ketoaldehyde that is produced endogenously and present in the environment and foods. It can modify DNA and proteins to form advanced glycation end products (AGEs). Emerging evidence has shown that $N^{2}$-(1-carboxyethyl)-2'-deoxyguanosine $\left(N^{2}\right.$ $\mathrm{CEdG}$ ) is a major marker for AGE-linked DNA adducts. Here, we report, for the first time, the preparation of oligodeoxyribonucleotides (ODNs) containing individual diastereomers of $\mathrm{N}^{2}$ CEdG via a postoligomerization synthesis method, which provided authentic substrates for examining the replication and repair of this lesion. In addition, thermodynamic parameters derived from melting temperature data revealed that the two diastereomers of $N^{2}$-CEdG destabilized significantly the double helix as represented by a $4 \mathrm{kcal} / \mathrm{mol}$ increase in Gibbs free energy for duplex formation at $25^{\circ} \mathrm{C}$. Primer extension assay results demonstrated that both diastereomers of $N^{2}$-CEdG could block considerably the replication synthesis mediated by the exonuclease-free Klenow fragment of Escherichia coli DNA polymerase I. Strikingly, the polymerase incorporated incorrect nucleotides, dGMP and dAMP, opposite the lesion more preferentially than the correct nucleotide, dCMP.
\end{abstract}

\section{Introduction}

Humans are exposed to methylglyoxal (MG), a highly reactive $\alpha$-ketoaldehyde, from a variety of sources. General exogenous sources of MG include cigarette smoke ${ }^{1}$, food and beverages such as soy sauce, coffee and whiskey ${ }^{2,3}$. On the other hand, the fragmentation of triose phosphate during glycolysis, metabolism of acetone, and catabolism of aminoacetone all contribute to the endogenous formation of $\mathrm{MG}^{4,5}$. Many factors, including aging, hyperglycemia, inflammation, oxidative stress and uremia, could enhance the accumulation of MG in vivo ${ }^{6}$. In this respect, as high as $310 \mu \mathrm{M}$ of methylglyoxal was detected in Chinese hamster ovary cells ${ }^{7}$. In addition, a previous clinical study indicated that the median level of MG increased by several fold in blood samples from type I and II diabetic patients, and the concentration of MG correlates positively with the duration and development of type I diabetes ${ }^{8}$.

As a reactive dicarbonyl compound, $\mathrm{MG}$ is involved in numerous pathological processes in vivo by binding irreversibly to proteins, primarily on arginine residues ${ }^{9-11}$, DNA and other substrates to form advanced glycation end products (AGEs) ${ }^{12,13}$. If remain unrepaired,

\footnotetext{
*To whom correspondence should be addressed: Telephone: (951) 827-2700. Fax: (951) 827-4713. yinsheng.wang@ucr.edu. Supporting Information Available

NMR spectra of synthetic compounds, MS and MS/MS of 20mer ODNs. This material is available free of charge via the Internet at http://pubs.acs.org.
} 
those AGEs could eventually lead to the inhibition of enzyme activity ${ }^{14}$, transcription activation ${ }^{15}$ and apoptosis 16 .

Several MG adducts of DNA have been previously reported, and guanine is the predominant modification site induced by MG when calf thymus DNA was used as substrate ${ }^{13,17,18}$. In an earlier study, $N^{2}$-(1-carboxyethyl)-9-methylguanine was formed from the incubation of 9methylguanine with glucose or MG, thus it was postulated that $N^{2}$-(1-carboxyethyl)-2'deoxyguanosine $\left(N^{2}-\mathrm{CEdG}\right)$ could be induced in DNA by MG ${ }^{19}$. Indeed Frischmann $e t$ al. ${ }^{13}$ showed recently that $N^{2}$-CEdG was the stable adduct formed in calf thymus DNA upon prolonged exposure to $\mathrm{MG}$ at physiological concentration and temperature. These authors further proposed that the $N^{2}-\mathrm{CEdG}$ could be produced from either direct coupling of $2^{\prime}$-deoxyguanosine (dG) with MG or from the conversion of 1, $N^{2}$-(1,2-dihydroxy-2methyl)ethano-2'-deoxyguanosine (cMG-dG) (Scheme 1).

$N^{2}$-CEdG was also detected in urine samples from healthy human subjects using immunoaffinity chromatography with a polyclonal antibody raised against $N^{2}-\mathrm{CEdG}{ }^{20}$, and the lesion was found to occur more frequently in kidney and aorta cells of diabetic and uremic patients ${ }^{21}$. Moreover, the lesion was found in cultured human smooth muscle cells and bovine aorta endothelium cells with the same immunoassay technique ${ }^{20}$.

Prior studies have demonstrated that methylglyoxal-DNA adducts could induce single strand breaks and high mutation frequencies in Escherichia coli $\left(\right.$ E. coli)cells ${ }^{22}$, and $\mathrm{G}: \mathrm{C} \rightarrow \mathrm{C}: \mathrm{G}$ and $\mathrm{G}: \mathrm{C} \rightarrow \mathrm{T}: \mathrm{A}$ transversions in $\sup F$ gene in mammalian cells ${ }^{23}$. In these previous mutagenesis studies, lesion-containing DNA substrates were prepared via the direct treatment of undamaged DNA with dihydroxyacetone or methylglyoxal ${ }^{14,16,22,23}$. The identity and homogeneity of adducts, however, were not carefully examined. In this context, it is known that the commercially available methylglyoxal is likely to be contaminated with formaldehyde and other impurities such as pyruvate, lactate and formate ${ }^{24}$, which may induce side reactions and complicate the interpretation of the results. We sought to understand the biological implications of $N^{2}$-CEdG at the molecular level. As a first step toward that goal, herein, we developed a postoligomerization method for the site-specific and stereospecific insertion of $N^{2}$-CEdG into ODNs. We also examined the effects of $N^{2}$ CEdG on duplex stability and carried out in vitro replication studies on the lesion-bearing substrates with Klenow fragment.

\section{Experimental Procedures}

\section{Materials}

All chemicals, unless otherwise specified, were from Sigma-Aldrich (St. Louis, MO) or EM Science. Common reagents for solid-phase DNA synthesis were obtained from Glen Research Co. (Sterling, VA), and unmodified ODNs used in this study were purchased from Integrated DNA Technologies (Coralville, IA). $\left[\gamma^{3}{ }^{32} \mathrm{P}\right] \mathrm{ATP}$ was obtained from Amersham Biosciences Co. (Piscataway, NJ).

\section{Mass spectrometry (MS), NMR and circular dichroism (CD)}

Electrospray ionization-mass spectrometry (ESI-MS) and tandem MS (MS/MS) experiments were carried out on an LCQ Deca XP ion-trap mass spectrometer (Thermo Fisher Scientific, San Jose, CA). A mixture of acetonitrile and water (50:50, v/v) was used as solvent for electrospray. The spray voltage was $3.0 \mathrm{kV}$, and the temperature of the heated capillary was maintained at $300^{\circ} \mathrm{C}$. High-resolution mass spectra (HRMS) were acquired on an Agilent 6210 TOF LC/MS instrument (Agilent Technologies, Palo Alto, CA) equipped with an electrospray ionization (ESI) source. ${ }^{1} \mathrm{H}$ NMR spectra were recorded at $300 \mathrm{MHz}$ on a Varian Inova $300 \mathrm{NMR}$ spectrometer, and ${ }^{31} \mathrm{P}$ NMR spectra were acquired at $80 \mathrm{MHz}$ on 
the same instrument. CD spectra were recorded on a JASCO J-815 CD spectrometer (JASCO Inc., Easton, MD).

HPLC

The purification of ODNs was performed on a Beckman HPLC System (32 Karat software version 3.0, pump module 125) with a UV detector (module 126) monitoring at $260 \mathrm{~nm}$. A $4.6 \times 250 \mathrm{~mm}$ Apollo C18 column (5 $\mu \mathrm{m}$ in particle size and $300 \AA$ in pore size, Alltech Associate Inc., Deerfield, IL) was used, and a 50-mM triethylammonium acetate buffer (TEAA, pH 6.6, Solution A) and a mixture of 50-mM TEAA and acetonitrile (70/30, v/v, Solution B) were employed as mobile phases. The flow rate was $0.8 \mathrm{~mL} / \mathrm{min}$. Three different HPLC gradients were used: (I) 5 min 0-20\% B, 40 min $20-40 \%$ B, 10 min 40$100 \% \mathrm{~B}$ and $5 \mathrm{~min}$ at $100 \% \mathrm{~B}$; (II) $5 \mathrm{~min} 0-30 \% \mathrm{~B}, 40 \mathrm{~min} 30-50 \% \mathrm{~B}, 10 \mathrm{~min} 50-100 \% \mathrm{~B}$ and $5 \mathrm{~min}$ at $100 \% \mathrm{~B}$; (III) $5 \min 0-30 \% \mathrm{~B}, 40 \mathrm{~min} 30-60 \% \mathrm{~B}, 10 \mathrm{~min} 60-100 \% \mathrm{~B}$ and 5 $\min$ at $100 \%$ B. The purified ODNs were desalted on the same HPLC system with $\mathrm{H}_{2} \mathrm{O}$ as mobile phase $\mathrm{A}$ and acetonitrile as mobile phase $\mathrm{B}$ where a gradient of $25 \mathrm{~min} 0 \% \mathrm{~B}, 2 \mathrm{~min}$ $0-60 \% \mathrm{~B}$ and $25 \mathrm{~min}$ at $60 \% \mathrm{~B}$ was employed.

\section{Synthesis of 5'-O-(4,4'-dimethoxytrityl)-2-fluoro- $0^{6}$-(trimethylsilylethyl)-2'-deoxyinosine (5, Scheme S1)}

Compound $\mathbf{5}$ was prepared following the previously published procedures (spectra shown in the Supporting Information) 25,26 .

\section{Synthesis of 5'-O-(4,4'-dimethoxytrityl)-2-fluoro- $O^{6}$-(trimethylsilylethyl)-2'-deoxyinosine-3'- O-[(2-cyanoethyl)- $N, N$-diisopropyl-phosphoramidite] (6, Scheme S1)}

To a flask, which was suspended in an ice bath and contained a solution of compound $\mathbf{5}$ (100 $\mathrm{mg}, 0.149 \mathrm{mmol}$ ) in dry $\mathrm{CH}_{2} \mathrm{Cl}_{2}(1.5 \mathrm{~mL})$, was added $N, N$-diisopropylethylamine (DIEA, $52 \mu \mathrm{L}, 0.298 \mathrm{mmol}$ ) followed by dropwise addition of 2-cyanoethyl- $N N$, -diisopropyl chlorophosphoramidite $(50 \mu \mathrm{L}, 0.224 \mathrm{mmol})$. The mixture was stirred at room temperature for 30 min under argon atmosphere. The reaction was quenched by cooling the mixture in an ice bath followed by slow addition of $\mathrm{CH}_{3} \mathrm{OH}(0.40 \mathrm{~mL})$. The solution was quickly extracted with EtOAc $(8 \mathrm{~mL})$, and the organic layer was washed with saturated $\mathrm{NaHCO}_{3}(4$ $\mathrm{mL})$ and brine $(4 \mathrm{~mL})$ and then dried with anhydrous $\mathrm{Na}_{2} \mathrm{SO}_{4}$. The solvent was evaporated in vacuo to yield 6 in white foam that was used directly for ODN synthesis. ${ }^{31} \mathrm{P}$ NMR $\left(\mathrm{CDCl}_{3}\right): \delta 149.9,149.8$. ESI-MS: $m / z 873.1[\mathrm{M}+\mathrm{H}]^{+}$.

\section{Synthesis of standard S- and R- $N^{2}-C E d G$}

L- or D-alanine ( $2 \mathrm{mg}, 24.5 \mu \mathrm{mol})$ was added to a mixture containing 2-fluoro- $O^{6}$ (trimethylsilylethyl)-2'-deoxyinosine $(2 \mathrm{mg}, 5.8 \mu \mathrm{mol})$, DMSO $(500 \mu \mathrm{L})$ and diisopropylethylamine (DIEA, $100 \mu \mathrm{L}$ ). The resulting solution was stirred at $55^{\circ} \mathrm{C}$ for $48 \mathrm{~h}$, and the solvent was removed in vacuo. The dried residues were dissolved in 5\% acetic acid and stirred at room temperature for $1 \mathrm{~h}$. The S- and R- $N^{2}$-CEdG were then isolated from the resulting reaction mixtures by HPLC.

\section{S- $N^{2}-C E d G$}

${ }^{1} \mathrm{H}$ NMR (300 MHz, $\left.\mathrm{D}_{2} \mathrm{O}, 25^{\circ} \mathrm{C}\right): \delta 7.96(\mathrm{~s}, 1 \mathrm{H}, \mathrm{H}-8), 6.35$ (t, $\left.1 \mathrm{H}, \mathrm{H}-1^{\prime}, J=6.6 \mathrm{~Hz}\right), 4.66(\mathrm{~m}$, $\left.1 \mathrm{H}, \mathrm{H}-3^{\prime}\right), 4.29$ (q, 1H, CH, $\left.J=7.3 \mathrm{~Hz}\right), 4.10\left(\mathrm{~m}, 1 \mathrm{H}, \mathrm{H}-4^{\prime}, J=9.9,4.1 \mathrm{~Hz}\right), 3.78(\mathrm{~m}, 2 \mathrm{H}$, H-5' and H-5"), 2.97 (m, 1H, H-2'), $2.54\left(\mathrm{~m}, 1 \mathrm{H}, \mathrm{H}-2^{\prime \prime}\right), 1.47$ (d, 3H, $\left.\mathrm{CH}_{3}, J=7.3 \mathrm{~Hz}\right)$ (Figure S6). HRMS (ESI): $[\mathrm{M}+\mathrm{Na}]^{+}$calcd $\mathrm{m} / z$ 362.1077, found 362.1078 . 


\section{R-N $N^{2}-$ CEdG}

${ }^{1} \mathrm{H}$ NMR (300 MHz, $\left.\mathrm{D}_{2} \mathrm{O}, 25^{\circ} \mathrm{C}\right): \delta 7.92(\mathrm{~s}, 1 \mathrm{H}, \mathrm{H}-8), 6.33\left(\mathrm{t}, 1 \mathrm{H}, \mathrm{H}-1^{\prime}, J=6.9 \mathrm{~Hz}\right), 4.66$ $\left(\mathrm{m}, 1 \mathrm{H}, \mathrm{H}-3^{\prime}\right), 4.24$ (q, 1H, CH, J = 7.3 Hz), $4.09\left(\mathrm{~m}, 1 \mathrm{H}, \mathrm{H}-4^{\prime}, J=6.3,4.1 \mathrm{~Hz}\right), 3.85$ (m, $2 \mathrm{H}, \mathrm{H}-5^{\prime}$ and $\left.\mathrm{H}-5^{\prime \prime}\right), 3.11$ (m, 1H, H-2'), 2.44 (m, 1H, H-2"), 1.47 (d, 3H, $\mathrm{CH}_{3}, J=7.3 \mathrm{~Hz}$ ) (Figure S7). HRMS (ESI): [M+Na] ${ }^{+}$calcd $\mathrm{m} / z$ 362.1077, found 362.1082 .

\section{ODN synthesis}

ODNs (sequences shown in Table 1) were synthesized on a Beckman Oligo 1000S DNA synthesizer (Fullerton, CA) at $1 \mu \mathrm{mol}$ scale. The synthesized phosphoramidite building block was dissolved in anhydrous acetonitrile at a concentration of $0.07 \mathrm{M}$. Normal phosphoramidite building blocks (Glen Research Inc., Sterling, VA) of dA, dC, dG, and dT were employed, and standard ODN assembly protocol was used without any modification.

After synthesis, the products were cleaved from the controlled-pore glass (CPG) support and partially deprotected with $0.1 \mathrm{M} \mathrm{NaOH}(3 \mathrm{~mL})$ at room temperature for 8-12 $\mathrm{h}$. The supernatant was removed and the beads were washed with $\mathrm{H}_{2} \mathrm{O}(2 \times 3 \mathrm{~mL})$. The combined aqueous solution was neutralized with $0.1 \mathrm{M}$ acetic acid to $\mathrm{pH} 7.0$ and lyophilized to dryness. The dried residue was mixed with DIEA $(150 \mu \mathrm{L}, 0.86 \mathrm{mmol})$, L-alanine or Dalanine $(4 \mathrm{mg}, 0.045 \mathrm{mmol})$ and DMSO $(500 \mu \mathrm{L})$. After being stirred at $55^{\circ} \mathrm{C}$ for $48-72 \mathrm{~h}$, the reaction mixture was allowed to cool to room temperature and dried. Concentrated $\mathrm{NH}_{4} \mathrm{OH}(600 \mu \mathrm{L})$ was added and the tightly sealed vial was heated at $55^{\circ} \mathrm{C}$ for $6-8 \mathrm{~h}$. After cooling to room temperature, the solvent was removed by using a Speed-Vac. The dried pellet was reconstituted in water and purified by using reversed-phase HPLC with gradient I for ODN1/ODN2 and gradient II for ODN3/ODN4 (Table 1) to give $O^{6}$-trimethylsilylethyl $\left(O^{6}\right.$-tse)-protected oligomers. The fraction containing $O^{6}$-tse-protected oligomer was collected, dried and the dried residue was treated with $5 \%$ acetic acid $(500 \mu \mathrm{L})$ at room temperature for $2 \mathrm{~h}$, neutralized with $1.0 \mathrm{M} \mathrm{NaOH}$, and purified by reversed-phase HPLC to yield the fully-deprotected ODNs (Scheme 2). In this respect, gradient I was employed for the purification of ODN1/ODN2, whereas gradient III was used for the purification of ODN3/ODN4.

\section{Enzymatic digestion of synthetic ODNs}

One unit of nuclease P1, 0.01 unit of calf spleen phosphodiesterase, and $2.5 \mu \mathrm{L}$ buffer solution, which contained sodium acetate $(300 \mathrm{mM}, \mathrm{pH} 5.0)$ and zinc acetate $(10 \mathrm{mM})$, were added to a $20-\mu \mathrm{L}$ solution of ODN1 or ODN2 (10 nmol). The digestion was continued at $37^{\circ} \mathrm{C}$ for $6 \mathrm{~h}$. To the digestion mixture were then added 10 units of alkaline phosphatase, 0.05 unit of snake venom phosphodiesterase, and $5 \mu \mathrm{L}$ of $0.5 \mathrm{M}$ Tris- $\mathrm{HCl}(\mathrm{pH}$ 8.9). The digestion was continued at $37^{\circ} \mathrm{C}$ for $6 \mathrm{~h}$, and the enzymes were removed by passing through a 10-kDa cut-off Centricon membrane (Millipore, Billerica, MA). The resulting mixtures were subjected subsequently to HPLC analysis, which was carried out on an Agilent 1100 HPLC system with a UV detector monitoring at $260 \mathrm{~nm}$. A 4.6×250 mm Apollo C18 column was used, and a 10-mM ammonium formate buffer $(\mathrm{pH} 6.9$, Solution $\mathrm{A})$ and a mixture of $10-\mathrm{mM}$ ammonium formate and acetonitrile $(70 / 30, \mathrm{v} / \mathrm{v}$, Solution B) were employed as mobile phases. The flow rate was $0.8 \mathrm{~mL} / \mathrm{min}$ where a gradient of $5 \mathrm{~min} 0-10 \% \mathrm{~B}$ followed by $40 \mathrm{~min} 10-40 \%$ B was employed.

\section{Thermodynamic studies}

UV absorbance-versus-temperature profiles were recorded on a Varian Cary 500 spectrophotometer (Varian, Inc., Palo Alto, CA). The modified ODNs and their complementary strands were dissolved in a $1.2-\mathrm{mL}$ solution containing $100 \mathrm{mM} \mathrm{NaCl}, 10$ $\mathrm{mM}$ sodium phosphate ( $\mathrm{pH} 7.0$ ), and $50 \mu \mathrm{M}$ EDTA at a total ODN concentration (Ct) of 1.0, 
$2.0,4.0,8.0$, or $16 \mu \mathrm{M}$. The absorbance was recorded in the reverse and forward directions for a temperature range of $80-10^{\circ} \mathrm{C}$ at the rate of $1{ }^{\circ} \mathrm{C} / \mathrm{min}$, and the melting temperature $\left(\mathrm{T}_{\mathrm{m}}\right)$ value was obtained by the derivative method. The thermodynamic parameters were obtained from the van't Hoff plot ${ }^{27}$, in which the reciprocal of $T_{m}$ was plotted against $\ln \left(C_{t} / 4\right)$ :

$$
\frac{1}{T_{m}}=\frac{R}{\Delta H} \ln \frac{C t}{4}+\frac{\Delta S}{\Delta H}
$$

and

$$
\Delta G=\Delta H-T \Delta S
$$

where $R$ is the universal gas constant $\left(1.987 \mathrm{cal} \mathrm{mol}^{-1} \mathrm{~K}^{-1}\right)$. The error limits for $\Delta G, \Delta H$, and $\Delta S$ derived from fitted parameters were calculated by using the previously described equations ${ }^{28,29}$.

\section{In vitro replication studies with exonuclease-free Klenow fragment of $E$. coli DNA polymerase I $\left(\mathbf{K f}^{-}\right)$}

The primer extension experiments were carried out under standing-start conditions. The 20mer lesion-containing template (ODN3/4) or normal template $(5 \mathrm{nM})$ with $\mathrm{dG}$ in lieu of the $N^{2}$-CEdG was annealed with a $5^{\prime}-\left[{ }^{32} \mathrm{P}\right]$-labeled 15 mer primer $(10 \mathrm{nM})$, to which were then added a mixture of all four dNTPs $(200 \mu \mathrm{M}$ each) and the Klenow fragment. The reaction was carried out in a $20-\mu \mathrm{L}$ solution containing $10 \mathrm{mM}$ Tris- $\mathrm{HCl}(\mathrm{pH} 7.5), 10 \mathrm{mM}$ $\mathrm{MgCl}_{2}, 50 \mathrm{mM} \mathrm{NaCl}$ and $1 \mathrm{mM}$ dithiothreitol (DTT) at $37^{\circ} \mathrm{C}$ for $60 \mathrm{~min}$. In vitro replication experiments were also carried out in the presence of one type of dNTP at a time; the concentration of dNTP was $1.0 \mathrm{mM}, 0.1$ unit of Klenow fragment was added, and the reaction was continued at $37^{\circ} \mathrm{C}$ for $10 \mathrm{~min}$.

The reaction was terminated by adding $8 \mu \mathrm{L}$ gel-loading buffer, which contained $80 \%$ formamide, $10 \mathrm{mM}$ EDTA at $\mathrm{pH} 8.0,1 \mathrm{mg} / \mathrm{mL}$ xylene cyanol, and $1 \mathrm{mg} / \mathrm{mL}$ bromophenol. The products were resolved on $20 \%$ denaturing polyacrylamide gels containing $8 \mathrm{M}$ urea. Gel images were obtained by using a Typhoon 9410 Variable Mode Imager (Amersham Biosciences Co.) and ImageQuant 5.2 software (Amersham Biosciences Co.).

\section{Results}

\section{Synthesis of $\mathrm{N}^{2}$-CEdG-containing ODNs}

Site-specific incorporation of $N^{2}$-CEdG into ODNs has not been reported, though treatment of unmodified DNA with 1,3-dihydroxyacetone or methylglyoxal was previously employed for the introduction of the lesion into DNA for mutagenesis studies 14,16,22,23. However, the identity and homogeneity of the products induced by 1,3-dihydroxyacetone or methylglyoxal were not carefully assessed. Herein, we developed a postoligomerization method for the site-specific insertion of $N^{2}$-CEdG into ODNs (Scheme 2). The method utilized the activity of the precursor nucleoside, 2-fluoro-2'-deoxyinosine (FdI), which was first synthesized and applied for the postoligomerization synthesis of $N^{2}$-guanine-adductcontaining ODNs by Harris and coworkers 25,26 . We reasoned that the nucleophilic attack by the $\mathrm{NH}_{2}$ group of alanine should also displace the fluoride in FdI and afford the desired $\mathrm{N}^{2}$ CEdG adducts. Additionally, the availability of two enantiomers of alanine should offer us the opportunity to generate separately ODNs carrying either of the two diastereomeric lesions (Schemes 1\&2). 
To test this idea, we first carried out the reaction at the mononucleoside level. In this respect, we treated 2-fluoro- $O^{6}$-(trimethylsilylethyl)-2'-deoxyinosine with L- or D-alanine, removed the trimethylsilylethyl group in the resulting nucleoside with $5 \%$ acetic acid, isolated the modified nucleoside from the reaction mixtures by HPLC (See Experimental), and characterized the products by NMR, MS and circular dichroism spectroscopy. It turned out that the ${ }^{1} \mathrm{H}$-NMR spectra for the above synthetic S- and R- $N^{2}$-CEdG were consistent with the previously reported data (Figures S6\&S7) ${ }^{30}$. In addition, the measured masses for these two modified nucleosides were in keeping with the calculated ones (See Experimental). Moreover, the independently prepared R- and S- $N^{2}$-CEdG exhibited similar traces, yet opposite features in CD signals (Figure 1), supporting that they are indeed diastereomers.

Having established that the synthetic route allowed for the successful preparation of the Rand S- $N^{2}$-CEdG, we next synthesized the phosphoramidite building block of 2-fluoro- $O^{6}$ (trimethylsilylethyl)-2'-deoxyinosine following the published procedures except that compound 5 (Scheme S1) was phosphitylated with 2-cyanoethyl- $N, N$ -

diisopropylchlorophosphoramidite instead of 2-cyanoethyl- $N, N, N^{\prime}, N^{\prime}$-tetraisopropyl phosphoramidite ${ }^{25,26}$. By using this building block, we then synthesized several ODNs.

After being cleaved from the CPG support, the partially deprotected ODNs were treated with either L- or D-alanine to achieve stereospecific formation of S- $N^{2}-\mathrm{CEdG}$ and R- $N^{2}$ $\mathrm{CEdG}$, respectively (Scheme 2). The temperature and time for this treatment were optimized to minimize the degradation and maximize the formation of the desired product. It turned out that the best results were obtained after ODN1/ODN2 and ODN3/ODN4 were treated with alanine at $55^{\circ} \mathrm{C}$ for $48 \mathrm{~h}$ and $72 \mathrm{~h}$, respectively. In this regard, the reaction did not proceed to completion in reasonable incubation time at lower temperature, whereas slightly more side products and the spontaneous removal of $O^{6}$-trimethylsilylethyl protecting group were observed at higher temperature.

After incorporating the $N^{2}$-carboxyethyl functionality into ODNs, we removed completely the protecting group on normal nucleobases by treatment with concentrated $\mathrm{NH}_{4} \mathrm{OH}$, under which conditions the $O 6$-trimethylsilylethyl protecting group remained intact. Because the $O^{6}$-(trimethylsilylethyl)- $N^{2}$-CEdG-bearing ODNs could be readily resolved by HPLC from the corresponding ODNs containing unmodified dG or FdI (Figures 2a and 3a), we separated the mixture by HPLC prior to removing the trimethylsilylethyl protecting group. After the HPLC separation and the removal of the trimethylsilylethyl group with 5\% acetic acid treatment, we separated again the resulting mixture by HPLC to obtain the desired lesion-bearing ODN substrates (Figures $2 b$ and $3 b$ ).

We next assessed the stability of lesion in ODNs by incubating the ODNs in $50 \mathrm{mM}$ phosphate buffer ( $\mathrm{pH} \mathrm{7.0)}$ at $37^{\circ} \mathrm{C}$ for up to $72 \mathrm{~h}, \mathrm{LC}-\mathrm{MS} / \mathrm{MS}$ analysis revealed that there is no obvious degradation of the lesion (data not shown).

\section{ESI-MS and MS/MS characterizations of ODNs containing an $\mathbf{N}^{2}$-CEdG}

We next characterized the above ODNs by ESI-MS and MS/MS (Table 1, NFigure 4, and Figure S8). Here, we chose to use d(GAGTAGXATGAG) (ODN1, X represents S-2 ${ }^{2}$ CEdG) as an example to illustrate how we use ESI-MS and MS/MS to confirm the site of $N^{2}$-CEdG incorporation. ESI-MS showed that the deconvoluted mass of ODN1 is $72 \mathrm{Da}$ higher than the calculated mass of the unmodified d(GAGTAGGATGAG) (Table 1, NFigure 4a), which is consistent with the presence of an ${ }^{2}$-CEdG adduct in this substrate. Moreover, highresolution ESI-MS result revealed that the measured $\mathrm{m} / \mathrm{z}$ for the monoisotopic peak of the $[\mathrm{M}-3 \mathrm{H}]^{3-}$ ion was 1280.550 , which differed from the calculated $\mathrm{m} / z$ of 1280.558 for the corresponding peak by only $6.3 \mathrm{ppm}$ (Figure S9). Moreover, the experimentally determined isotope profile was consistent with the calculated one (Figure S9). 
The product-ion spectrum of the $[\mathrm{M}-4 \mathrm{H}]^{4-}$ ion $(\mathrm{m} / \mathrm{z}, 960.6$, Figure $4 \mathrm{~b})$ of the ODN showed the formation of $\mathrm{w}_{\mathrm{n}}$ ions, that is, $\mathrm{w}_{1}{ }^{-}, \mathrm{w}_{2}{ }^{-}, \mathrm{w}_{4}{ }^{-}, \mathrm{w}_{5}{ }^{-}, \mathrm{w}_{6}{ }^{2-}, \mathrm{w}_{7} 7^{2-}, \mathrm{w}_{9}{ }^{3-}, \mathrm{w}_{10} 0^{3-}$ and $\mathrm{w}_{11}{ }^{4-}$ and $\left[\mathrm{a}_{\mathrm{n}}-\mathrm{Base}\right]$ ions, that is, $\left[\mathrm{a}_{2}-\mathrm{A}\right]^{-},\left[\mathrm{a}_{3}-\mathrm{G}\right]^{-},\left[\mathrm{a}_{5}-\mathrm{A}\right]^{-},\left[\mathrm{a}_{6}-\mathrm{G}\right]^{-},\left[\mathrm{a}_{7}-\mathrm{X}\right]^{2-},\left[\mathrm{a}_{8}-\mathrm{A}\right]^{2-}$ and $\left[\mathrm{a}_{10}-\mathrm{G}\right]^{3-}$ ions [nomenclature for fragment ions follows that reported by McLuckey et al. ${ }^{31}$; "A", "C", and "G" represent adenine, cytosine, and guanine, respectively]. The measured masses for the $\mathrm{w}_{1}, \mathrm{w}_{2}, \mathrm{w}_{4}$, and $\mathrm{w}_{5}$ ions were the same as the calculated masses for the corresponding ions of the unmodified ODN, whereas the $\mathrm{w}_{6}, \mathrm{w}_{7}, \mathrm{w}_{9}, \mathrm{w}_{10}$ and $\mathrm{w}_{11}$ ions exhibited $72 \mathrm{Da}$ higher in mass than the corresponding fragments formed from the unmodified d(GAGTAGGATGAG). These results are consistent with the presence of an $\mathrm{N}^{2}$ CEdG at the seventh position in the ODN. The above conclusion is further substantiated by the observed masses for the $\left[a_{n}-B a s e\right]$ ions. In this respect, the measured masses for the $a_{8}$ - A] and $\left[\mathrm{a}_{10}-\mathrm{G}\right]$ ions are $72 \mathrm{Da}$ higher than, whereas the measured masses of the $\left[\mathrm{a}_{2}-\mathrm{A}\right]$, $\left[a_{3}-G\right],\left[a_{5}-A\right],\left[a_{6}-G\right]$ and $\left[a_{7}-X\right]$ ions are the same as the calculated ones of the corresponding fragment ions for the unmodified d(GAGTAGGATGAG). The sequences of ODN3 and ODN4 were also confirmed by the similar ESI-MS and MS/MS analyses (Figure S8 shows the MS and MS/MS for ODN3).

\section{Homogeneity and Purity of Synthetic ODNs}

To confirm the stereospecific incorporation of S- and R- $N^{2}-$ CEdG into ODNs, we further digested ODNs $1 \& 2$ into mononucleosides (See Experimental) and separated the digestion mixtures by HPLC. For comparison, we also analyzed synthetic S- $N^{2}-\mathrm{CEdG}, \mathrm{R}-N^{2}-\mathrm{CEdG}$ as well as standard dG, dT and dA by HPLC under identical experimental conditions (Figure 5). Indeed the HPLC traces revealed the presence of R- $N^{2}-\mathrm{CEdG}$ in the digestion mixture of ODN2 (the 17.1-min fraction, Figure 5b\&d), whereas the $\mathrm{S}-N^{2}-\mathrm{CEdG}$ was not detectable. Likewise, S- $N^{2}-\mathrm{CEdG}$, but not R- $N^{2}$-CEdG, was present in the digestion mixture of ODN1 (the 20.2-min fraction, Figure 5c\&e). The above results, therefore, demonstrated unambiguously that the postoligomerization method allowed for the independent incorporation of the two diastereomers of $N^{2}$-CEdG into ODNs. It is worth noting that the presence of residual adenosine deaminase in the commercial enzymes caused the deamination of some dA into 2'-deoxyinosine (dI, Figure 5d\&e). The identities of the mononucleosides liberated from the enzymatic digestion were confirmed by ESI-MS measurements (Data not shown). In this context, it is important to emphasize that highresolution ESI-MS results supported the absence of adenine deamination in the ODNs prior to the enzymatic digestion (vide supra).

We further integrated the peak areas for $N^{2}-\mathrm{CEdG}, \mathrm{dT}$, and dG in the HPLC traces for the digestion mixtures of ODNs $1 \& 2$ and estimated the molar ratios of these nucleosides based on the peak area ratios with the consideration of the molar extinction coefficients of the three nucleosides. In this regard, we measured, by using a previously described ${ }^{1} \mathrm{H}-\mathrm{NMR}$ method ${ }^{32}$, the extinction coefficient of $N^{2}-\mathrm{CEdG}$ at $260 \mathrm{~nm}$, which was $13,600 \mathrm{~L} \mathrm{~mol}^{-1}$ $\mathrm{cm}^{-1}$. It turned out that the estimated molar ratios of $N^{2}$-CEdG:dT:dG were 1.0:2.0:5.1 and 1.0:2.0:5.2 for ODN1 and ODN2, respectively, which are consistent with the presence of one $N^{2}$-CEdG, two dT and five dG residues in these two ODNs. Because of the deamination of $\mathrm{dA}$ to dI during enzymatic digestion (vide supra), the peak area for $\mathrm{dA}$ was not determined.

\section{Thermodynamic properties of lesion-containing DNA duplexes}

To examine how the presence of $N^{2}-\mathrm{CEdG}$ affects duplex stability, we further determined the thermodynamic parameters for the formation of duplex DNA harboring an $\mathrm{S}-\mathrm{N}^{2}$-CEdG, $\mathrm{R}-\mathrm{N}^{2}-\mathrm{CEdG}$, or unmodified dG by melting temperature measurements. The ODN sequences used in this study were listed in Table 1 , and the $\Delta H$ and $\Delta S$ were calculated from the intercept and slope found in the van't Hoff plot following the equations described in the 
Experimental Section (Figure 6). It turned out that the presence of S- $N^{2}-\mathrm{CEdG}$ and R- $N^{2}$ CEdG destabilized respectively the duplex by 3.8 and $4.0 \mathrm{kcal} / \mathrm{mol}$ in free energy at $25^{\circ} \mathrm{C}$ (Table 2). Correspondingly the presence of $N^{2}-\mathrm{CE}-\mathrm{dG}$ results in a marked decrease in melting temperature; at the total ODN concentration of $2.0 \mu \mathrm{M}$, the replacement of dG with an S- $N^{2}-\mathrm{CEdG}$ or R- $N^{2}-\mathrm{CEdG}$ leads to a drop in melting temperature from $43.6^{\circ} \mathrm{C}$ to $29.9^{\circ} \mathrm{C}$ and $29.2^{\circ} \mathrm{C}$, respectively.

\section{In vitro replication studies with Klenow fragment}

We next examined the bypass of $N^{2}-\mathrm{CEdG}$ with Klenow fragment by carrying out in vitro primer extension assays. To this end, we assessed the ability for the Klenow fragment, which has been used extensively as a model replicative polymerase, to extend a $5^{\prime}-\left[{ }^{32} \mathrm{P}\right]-$ labeled 15-mer primer annealed with a 20-mer, $N^{2}$-CEdG-bearing template in the presence of all four dNTPs. The primer extension results unveiled that the synthesis stops mostly after the incorporation of one nucleotide opposite $N^{2}$-CEdG for the lesion-bearing substrates, though a small percentage of bypass product could also be detected. However, the fulllength products from the replication of the undamaged template can be readily obtained (Figure 7a). In this regard, the percentages of the full-length products formed from the extension of the normal, S- and R- $N^{2}$-CEdG-bearing substrates in the presence of 0.3 unit of $\mathrm{Kf}^{-}$were estimated to be $80 \%, 22 \%$, and $5 \%$, respectively (Figure $7 \mathrm{a}$ ).

When the above primer/template complex was incubated with $\mathrm{Kf}^{-}$in the presence of one type of nucleotide at a time, we found that dGMP and dAMP were incorporated opposite the lesion with much greater efficiency than the correct nucleotide, dCMP. Moreover, the dAMP insertion was more favored while the template strand bears an S- $N^{2}$-CEdG than while it contains an R- $N^{2}$-CEdG (Figure 7b). In this context, we quantified the percentages of nucleotide incorporation by integrating the band intensities for the unextended primer and the extended products. It turned out that the percentages for the incorporation of dAMP, dGMP, dCMP, and dTMP opposite S- $N^{2}$-CEdG were $50 \pm 10 \%, 72 \pm 4 \%, 11 \pm 3 \%$, and $8 \pm 1 \%$, respectively. The corresponding percentages for the incorporation of these nucleotides opposite R- $N^{2}$-CEdG were $37 \pm 8 \%, 85 \pm 3 \%, 9 \pm 1 \%$, and $9 \pm 2 \%$, whereas the percentages for the insertion of corresponding nucleotides opposite $\mathrm{dG}$ in the control substrate were $30 \pm 1 \%$, $73 \pm 2 \%, 88 \pm 1 \%$, and $61 \pm 0.2 \%$ (These results were based on three or more independent measurements).

\section{Discussion}

Recently, a number of studies have shown that methylglyoxal is mutagenic in vivo $22,23,33$. Under physiological conditions, the major MG adduct of DNA was shown to be $\mathrm{N}^{2}$ CEdG ${ }^{13}$. Obtaining ODNs bearing a site-specifically incorporated $N^{2}$-CEdG constitutes a crucial step towards examining the biological implications of the lesion at the molecular level. In this study, we developed a facile postoligomerization method for the site-specific incorporation of individual diastereomers of $N^{2}$-CEdG into ODNs, which provided an opportunity to investigate the stereochemical effect on the replication and repair of $\mathrm{N}^{2}$ CEdG. We demonstrated that the method facilitated the preparation of 12- and 20mer ODNs in reasonably good yield. After HPLC separation and desalting, we were able to obtain 70$100 \mathrm{nmol}$ of the lesion-bearing ODNs from a $1-\mu \mathrm{mol}$ scale synthesis. Thus, the synthetic strategy facilitates the availability of sufficient ODN substrates for future NMR structural studies. In addition, these lesion-bearing substrates can be readily employed to construct, by enzymatic ligation, longer lesion-bearing ODNs for in-vitro DNA repair studies ${ }^{34}$. Likewise, the lesion-housing substrates can be ligated into plasmid DNA for in-vivo replication and repair studies 35 . 
Thermodynamic parameters for duplex formation, as derived from melting temperature measurements, revealed that the introduction of an $N^{2}-\mathrm{CEdG}$ into duplex DNA led to an increase in $\Delta G$ at $25^{\circ} \mathrm{C}$ by $3.8 \mathrm{kcal} / \mathrm{mol}$ and $4.0 \mathrm{kcal} / \mathrm{mol}$ for the $\mathrm{S}$ and R-diastereomers, respectively (Table 2). The increase in $\Delta G$ for duplex formation is in the similar range as those reported for some other single-nucleobase lesions. For instance, 8-oxo-7,8-dihydro-2'deoxyguanosine (8-oxodG) and 5,6-dihydroxy-5,6-dihydrothymidine (thymidine glycol) caused $3.4^{36}$ and $4.7 \mathrm{kcal} / \mathrm{mol}^{37}$ increase in free energy for duplex formation. In this context, it is of note that the presence of a carboxyethyl functionality on the $N^{2}$ position of guanine is expected to alter the Watson-Crick base pairing property of this nucleobase thereby destabilizing duplex DNA. Although the oxidation of dG to a 8-oxodG does not alter the hydrogen bonding properties of the nucleobase per se, the $\mathrm{N}$-glycosidic linkage in 8 -oxodG is known to equilibrate between the syn and anti conformations, with the former being energetically more favorable ${ }^{38}$. The presence of 8-oxodG in syn conformation renders this nucleobase to base pair preferentially with $\mathrm{dA}^{38}$. Similarly, the formation of thymidine glycol does not change the hydrogen bonding portion of the nucleobase itself; however, NMR structure studies indicated that thymidine glycol induces a large, localized structural change in duplex DNA with the modified nucleobase being extrahelical ${ }^{39}$. Therefore, the similar extent of destabilization to DNA double helix induced by $N^{2}$-CEdG, 8-oxodG and thymidine glycol suggest that the presence of an $N^{2}$-CEdG in duplex DNA may also cause significant change to local DNA structure.

The destabilization to duplex DNA induced by lesions may provide insights into recognition of the lesions by repair enzyme ${ }^{40}$. In this respect, nucleotide excision repair (NER) has been proposed to be involved in both the repair and the fixation of methylglyoxal-induced mutations ${ }^{41}$.

The $N^{2}$ position of guanine, located in the minor groove of duplex DNA, is a major site for modification induced by various carcinogens ${ }^{42}$. Previous studies showed that $N^{2}$ methylguanine could stall slightly the Klenow fragment-mediated primer extension reaction one base prior to the lesion, but DNA synthesis past the lesion was readily completed with small amount of misincorporation of dTMP ${ }^{43}$. On the other hand, $N^{2}$-ethylguanine could retard DNA synthesis but preferentially miscodes with dGMP when Klenow fragment was employed $^{44}$.

Our primer extension experiments with Klenow fragment demonstrated that $N^{2}$-CEdG blocked markedly the Klenow fragment-mediated DNA synthesis past the lesion site. In addition, the polymerase incorporated dGMP and dAMP opposite the lesion much more efficiently than the correct nucleotide, dCMP. This result suggests that the presence of the bulky $N^{2}$-carboxyethyl group in the minor groove may render the hydrogen bonding property of the modified guanine not to be recognized by the Klenow fragment during nucleotide insertion. Under such circumstances purine nucleotides can conceivably be incorporated more efficiently than pyrimidine nucleotides because the former nucleotides exhibit more favorable stacking interaction with the nucleotide at the $3^{\prime}$ terminus of the primer than the latter nucleotides ${ }^{45}$. In addition, the result of the in-vitro replication study is consistent with previous studies showing that $\mathrm{MG}$ induced $\mathrm{G}: \mathrm{C} \rightarrow \mathrm{C}: \mathrm{G}$ and $\mathrm{G}: \mathrm{C} \rightarrow \mathrm{T}: \mathrm{A}$ transversions in $s u p F$ gene in mammalian cells ${ }^{23}$. Moreover, the insertion of dAMP opposite the $\mathrm{S}$ diastereomer of $N^{2}$-CEdG occurs more readily than that opposite the R diastereomer, highlighting the effect of difference in stereochemistry on the selectivity of nucleotide incorporation.

Future steady-state kinetic measurements on nucleotide incorporation and in vivo mutagenesis studies with the structurely defined lesion-carrying substrates as described in this paper will further illuminate the genotoxic effects of MG at the molecular level. 


\section{Supplementary Material}

Refer to Web version on PubMed Central for supplementary material.

\section{Acknowledgments}

The authors want to thank the National Institutes of Health for supporting this research (Grants No. R01 CA96906 and R01 CA101864).

\section{References}

1. Moreetesta P, Saintjalm Y. J Chromatogr. 1981; 217:197-208.

2. Nagao M, Fujita Y, Wakabayashi K, Nukaya H, Kosuge T, Sugimura T. Environ Health Perspect. 1986; 67:89-91. [PubMed: 3757962]

3. Nagao M, Fujita Y, Sugimura T, Kosuge T. IARC Sci Publ. 1986:283-291. [PubMed: 3539787]

4. Kalapos MP. Toxicol Lett. 1999; 110:145-175. [PubMed: 10597025]

5. Phillips SA, Thornalley PJ. Eur J Biochem. 1993; 212:101-105. [PubMed: 8444148]

6. Ramasamy R, Yan SF, Schmidt AM. Cell. 2006; 124:258-260. [PubMed: 16439200]

7. Chaplen FWR, Fahl WE, Cameron DC. Proc Natl Acad Sci USA. 1998; 95:5533-5538. [PubMed: 9576917]

8. McLellan AC, Thornalley PJ, Benn J, Sonksen PH. Clin Sci. 1994; 87:21-29. [PubMed: 8062515]

9. Ahmed N, Thornalley PJ. Biochem J. 2002; 364:15-24. [PubMed: 11988071]

10. Gao Y, Wang YS. Biochemistry. 2006; 45:15654-15660. [PubMed: 17176087]

11. Oya T, Hattori N, Mizuno Y, Miyata S, Maeda S, Osawa T, Uchida K. J Biol Chem. 1999; 274:18492-18502. [PubMed: 10373458]

12. Lo TWC, Westwood ME, McLellan AC, Selwood T, Thornalley PJ. J Biol Chem. 1994; 269:32299-32305. [PubMed: 7798230]

13. Frischmann M, Bidmon C, Angerer J, Pischetsrieder M. Chem Res Toxicol. 2005; 18:1586-1592. [PubMed: 16533023]

14. Murata-Kamiya N, Kamiya H. Nucleic Acids Res. 2001; 29:3433-3438. [PubMed: 11504881]

15. Maeta K, Izawa S, Okazaki S, Kuge S, Inoue Y. Mol Cell Biol. 2004; 24:8753-8764. [PubMed: 15367692]

16. Fukunaga M, Miyata S, Liu BF, Miyazaki H, Hirota Y, Higo S, Hamada Y, Ueyama S, Kasuga M. Biochem Biophys Res Commun. 2004; 320:689-695. [PubMed: 15240103]

17. Shapiro R, Cohen BI, Shiuey SJ, Maurer H. Biochemistry. 1969; 8:238. [PubMed: 5777326]

18. Krymkiew N. FEBS Lett. 1973; 29:51-54. [PubMed: 11946906]

19. Papoulis A, Alabed Y, Bucala R. Biochemistry. 1995; 34:648-655. [PubMed: 7819260]

20. Schneider M, Georgescu A, Bidmon C, Tutsch M, Fleischmann EH, Popov D, Pischetsrieder M. Mol Nutr Food Res. 2006; 50:424-429. [PubMed: 16598809]

21. Li H, Nakamura S, Miyazaki S, Morita T, Suzuki M, Pischetsrieder M, Niwa T. Kidney Intl. 2006; 69:388-392.

22. Pischetsrieder M, Seidel W, Munch G, Schinzel R. Biochem Biophys Res Commun. 1999; 264:544-549. [PubMed: 10529399]

23. Murata-Kamiya N, Kamiya H, Kaji H, Kasai H. Mutat Res. 2000; 468:173-182. [PubMed: 10882894]

24. Pourmotabbed T, Creighton DJ. J Biol Chem. 1986; 261:14240-14244. [PubMed: 3771532]

25. Harris CM, Zhou L, Strand EA, Harris TM. J Am Chem Soc. 1991; 113:4328-4329.

26. DeCorte BL, Tsarouhtsis D, Kuchimanchi S, Cooper MD, Horton P, Harris CM, Harris TM. Chem Res Toxicol. 1996; 9:630-637. [PubMed: 8728509]

27. Breslauer KJ. Methods Enzymol. 1995; 259:221-242. [PubMed: 8538456]

28. Persmark M, Guengerich FP. Biochemistry. 1994; 33:8662-8672. [PubMed: 8038155]

29. Santalucia J, Kierzek R, Turner DH. J Am Chem Soc. 1991; 113:4313-4322. 
30. Ochs S, Severin T. Liebigs Ann Chem. 1994; 8:851-853.

31. McLuckey SA, Vanberkel GJ, Glish GL. J Am Soc Mass Spectrom. 1992; 3:60-70.

32. Hong H, Wang Y. J Am Chem Soc. 2005; 127:13969-13977. [PubMed: 16201819]

33. Seidel W, Pischetsrieder M. Cell Mol Biol. 1998; 44:1165-1170. [PubMed: 9846899]

34. Gu C, Zhang Q, Yang Z, Wang Y, Zou Y, Wang Y. Biochemistry. 2006; 45:10739-10746. [PubMed: 16939226]

35. Delaney JC, Essigmann JM. Methods Enzymol. 2006; 408:1-15. [PubMed: 16793359]

36. Plum GE, Grollman AP, Johnson F, Breslauer KJ. Biochemistry. 1995; 34:16148-16160. [PubMed: 8519772]

37. Iwai S. Chem Eur J. 2001; 7:4343-4351.

38. Grollman AP, Moriya M. Trends Genet. 1993; 9:246-249. [PubMed: 8379000]

39. Kao JY, Goljer I, Phan TA, Bolton PH. J Biol Chem. 1993; 268:17787-17793. [PubMed: 8349663]

40. Pilch DS, Plum GE, Breslauer KJ. Curr Opin Struct Biol. 1995; 5:334-342. [PubMed: 7583632]

41. Murata-Kamiya N, Kaji H, Kasai H. Mutat Res. 1999; 442:19-28. [PubMed: 10366769]

42. Guengerich FP. Chem Rev. 2006; 106:420-452. [PubMed: 16464013]

43. Yasui M, Matsui S, Ihara M, Laxmi YRS, Shibutani S, Matsuda T. Nucleic Acids Res. 2001; 29:1994-2001. [PubMed: 11328885]

44. Terashima I, Matsuda T, Fang TW, Suzuki N, Kobayashi J, Kohda K, Shibutani S. Biochemistry. 2001; 40:4106-4114. [PubMed: 11300791]

45. Saenger, W. Principles of Nucleic Acid Structure. Springer-Verlag New York Inc; New York: 1984. 


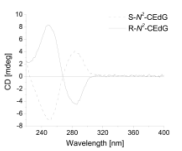

Figure 1.

CD spectra of standard S- $N^{2}-\mathrm{CEdG}$ and R- $N^{2}-\mathrm{CEdG}(50 \mu \mathrm{M})$. 


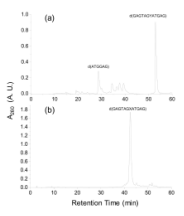

Figure 2.

HPLC traces for the separation of the synthesized 12mer ODNs: (a)

d(GAGTAGYATGAG), Y=O $O^{6}$-tse-S- $N^{2}$-CEdG; (b) d(GAGTAGXATGAG), X= S- $N^{2}$ CEdG. 


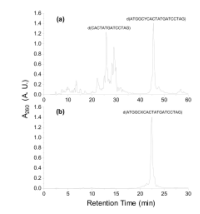

Figure 3.

HPLC traces for the separation of the synthesized 20mer ODNs: (a)

d(ATGGAYCACTATGATCCTAG), Y $=O^{6}$-tse-S- $N^{2}$-CEdG; (b) d(ATGGAXCACTATGATCCTAG), $\mathrm{X}=\mathrm{S}-\mathrm{N}^{2}-\mathrm{CEdG}$. 


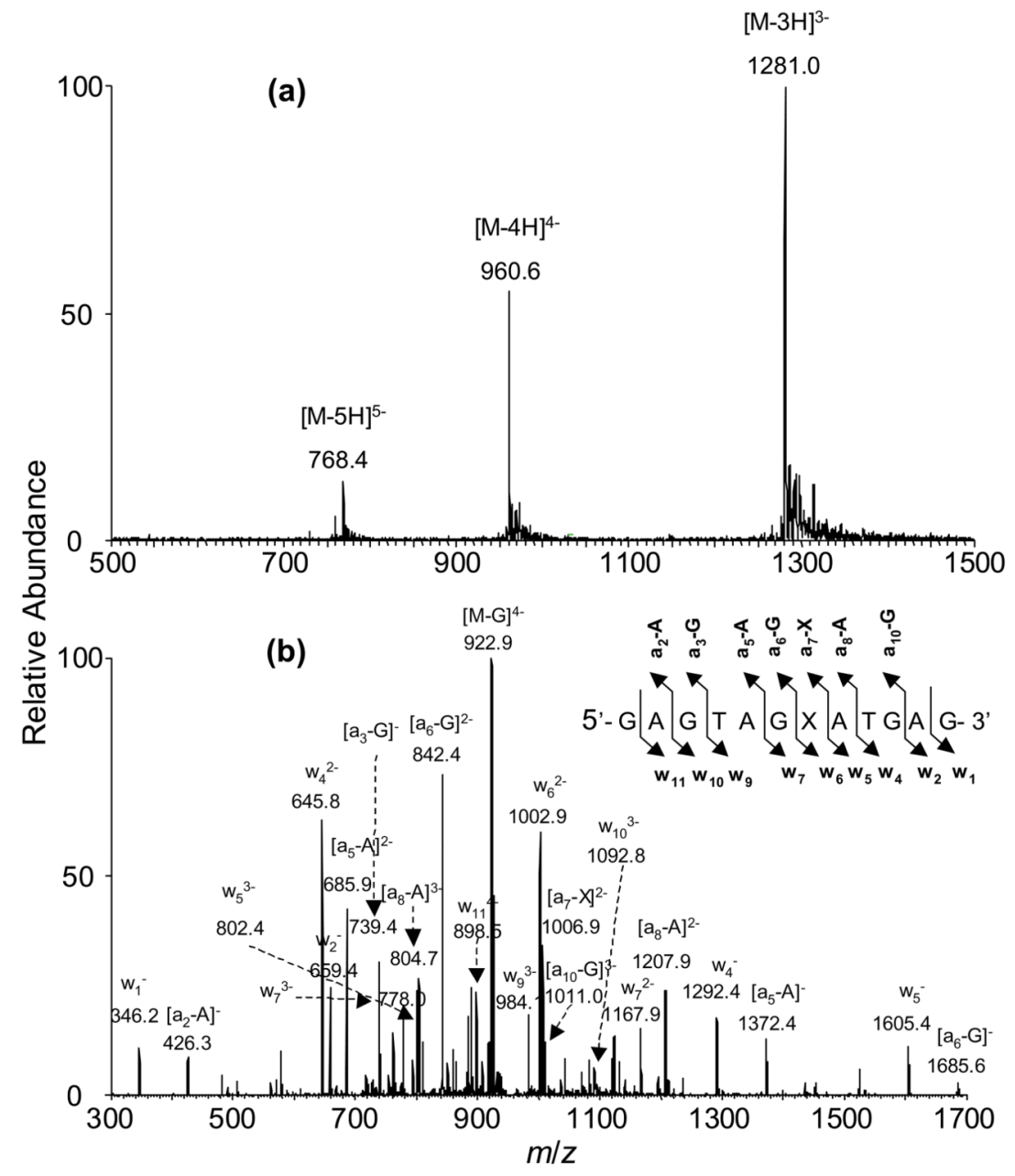

Figure 4.

ESI-MS and MS/MS characterizations of d(GAGTAGXATGAG), X=S- $N^{2}-\mathrm{CEdG}$ : (a) Negative-ion ESI-MS; (b) product-ion spectrum of the $[\mathrm{M}-4 \mathrm{H}]^{4-}$ ion $(\mathrm{m} / \mathrm{z}, 960.6)$. 


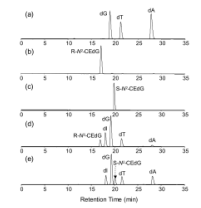

Figure 5.

HPLC traces for the separation of: (a) the mixture of dG, dT and dA; (b) R- $N^{2}-\mathrm{CEdG}$; (c) S$N^{2}$-CEdG; (d) the enzymatic digestion mixture of ODN2; and (e) the enzymatic digestion mixture of ODN1. A UV detector was set at $260 \mathrm{~nm}$ for monitoring the effluents. The presence of residual adenosine deaminase in the commercial enzymes caused the deamination of some $\mathrm{dA}$ to $\mathrm{dI}$. 


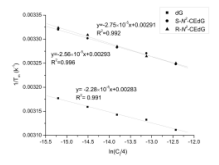

Figure 6.

Plots of $1 / T_{m}$ vs. $\ln \left(C_{t} / 4\right)$ for the duplex ODNs containing $d G$ and $N 2-C E d G$ adducts. The duplex is d(GAGTAGXATGAG)/d(CTCATCCTACTC), where X represents $\mathrm{dG}(\boldsymbol{\square}), \mathrm{S}-\mathrm{N}^{2}$ $\mathrm{CEdG}(\bullet)$ and $\mathrm{R}-N^{2}-\mathrm{CEdG}(\boldsymbol{\Delta})$. 


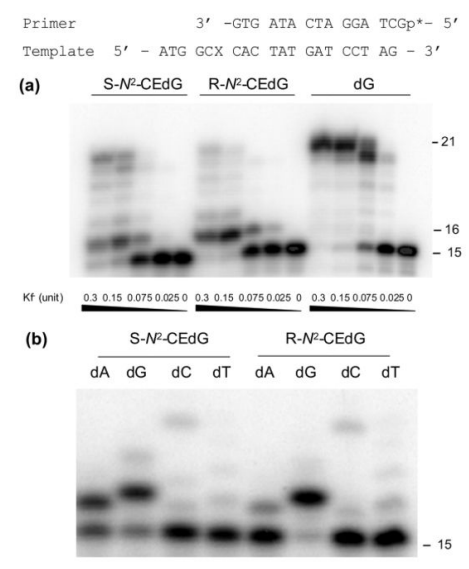

\section{Figure 7.}

In vitro replication studies of $N^{2}-\mathrm{CEdG}$-bearing and control undamaged substrates with Klenow fragment of $E$. coli polymerase I (X represents S- $N^{2}-\mathrm{CEdG}, \mathrm{R}-N^{2}-\mathrm{CEdG}$ or unmodified $\mathrm{dG}$ ). The concentrations of the primer and template were 5 and $10 \mathrm{nM}$, respectively, and the reaction volume was $20 \mu \mathrm{L}$. (a) The primer extension was carried out in the presence of all four dNTPs at a concentration of $200 \mu \mathrm{M}$ each, and the amounts $\mathrm{Kf}^{-}$ were as indicated in the figure. The reactions were continued at $37^{\circ} \mathrm{C}$ for $60 \mathrm{~min}$. (b) The reaction was performed in the presence of one type of $d N T P$ at a time $([\mathrm{dNTP}]=1.0 \mathrm{mM})$ at $37^{\circ} \mathrm{C}$ for $10 \mathrm{~min}$, and 0.1 unit of $\mathrm{Kf}^{-}$was used. 

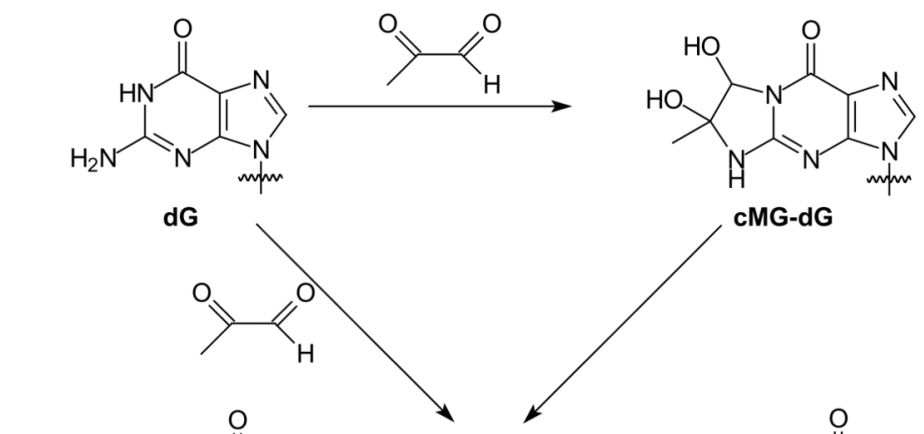

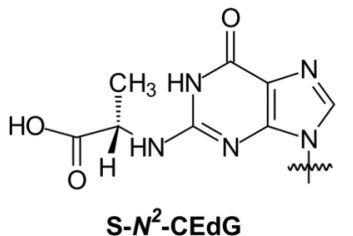

$N^{2}-((1 S)-1-$ Carboxyethyl)-2'-deoxyguanosine

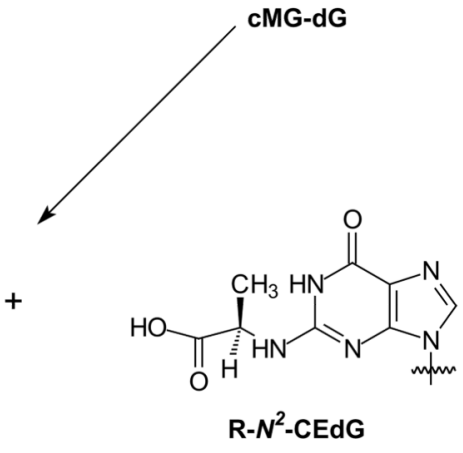

$N^{2}-((1 R)-1-$ Carboxyethyl)-2'-deoxyguanosine

Scheme 1.

Formation of $N^{2}$-CEdG. 


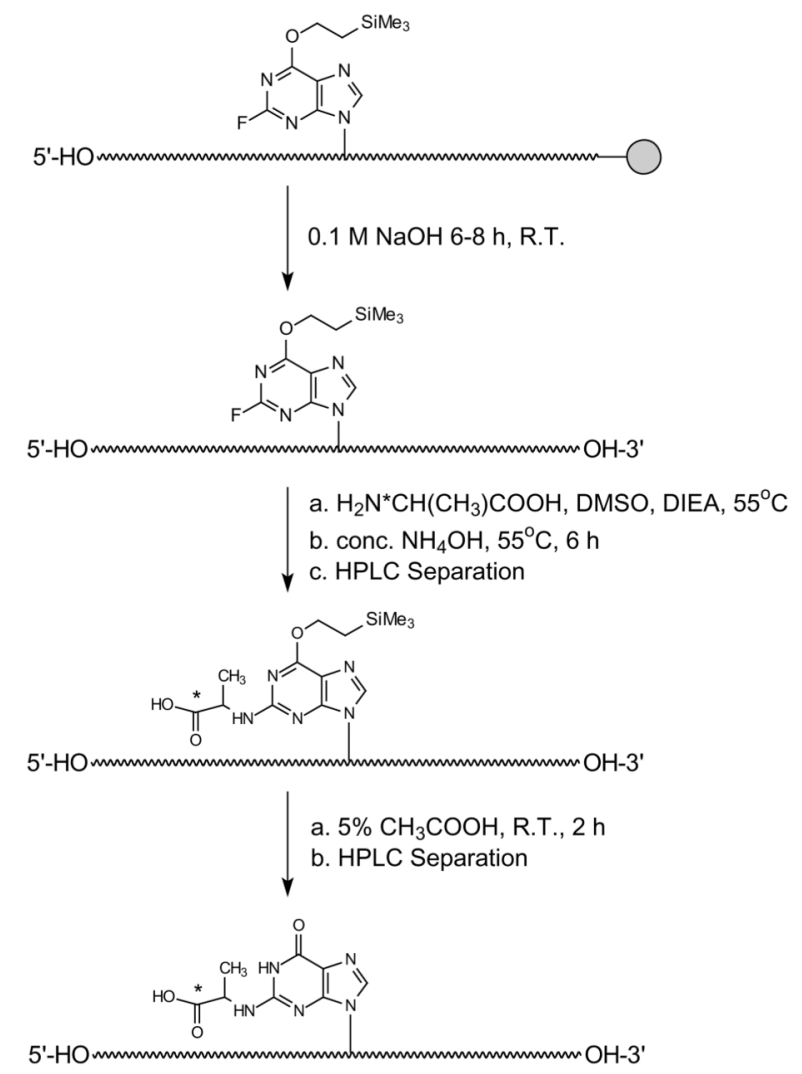

Scheme 2.

Postoligomerization method for the incorporation of $N^{2}-\mathrm{CEdG}$ into ODNs ("**" indicates the chiral carbon). 
Table 1

Sequences of Synthesized ODNs

\begin{tabular}{llcc}
\hline ODNs & sequences $^{\boldsymbol{a}}$ & observed $\boldsymbol{m} / \boldsymbol{z}$ & theoretical $\boldsymbol{m} / \boldsymbol{z}$ \\
\hline ODN1/2 & 5'-GAG TAG XAT GAG-3' $^{\prime}$ & 3845.0 & 3845.5 \\
ODN3/4 & 5'-ATG GCX CAC TAT GAT CCT AG-3' $^{\prime}$ & 6188.0 & 6188.1 \\
\hline
\end{tabular}

${ }^{a} \mathrm{ODN} 1 / \mathrm{ODN} 3, \mathrm{X}=\mathrm{S}-N^{2}$-CEG; ODN2/ODN4, X= R-N ${ }^{2}$-CEG. 
